\title{
Louise Bourgeois: an early modern midwife`s observations on female infertility ${ }^{1}$
}

\section{When the English midwife Sarah Stone published A Complete Practice of Midwifery.} Consisting of upwards of forty cases or observations in that valuable art, in 1737, her "Preface to the Reader" carefully separated the role of the midwife from that of physicians on questions concerning infertility. Stone declared:

I shall not fill any part of this book, with needless discourses on the Parts of Generation, nor the Reasons of Conception; neither shall I concern myself, or give my opinion, why some Women do not conceive; many Authors being copious on such Subjects. For my part, I think all the Disorders of Teeming Women do not belong to Midwives; but they ought to commit themselves to the Care of a Physician [.] (Stone xviii)

In the context of eighteenth-century England, where the rise of male-midwife surgeons became especially evident in towns (Wilson 164-169), this may well have been a side sweep at maleauthored works on childbirth and women's health. ${ }^{2}$ It may also have been an indirect criticism of the first manual which had been published in English under the name of a midwife, The Midwives Book or the Whole Art of Midwifery of 1671. Modern critics' uncertainties around the authorship of this popular work are significant for our understanding of the fault lines across western Europe between (female) midwives` and (male) physicians 'roles and authority in respect of infertility.

Although The Midwives Book was published under the apparent authorship of a Jane Sharp, there is no documentary evidence that there was a practising midwife of this name. ${ }^{3}$ Furthermore, the text reveals heavy borrowings from previous male-authored theoretical sources, Despite its author addressing the "Midwives of England" in the preface, the compendium is written in the tradition of Culpepper and Sennert, relying primarily on the authority of a panoply of earlier male medical writers - from England and the continent - albeit occasionally challenging some commonplace interpretations through a female-voiced corrective reading. ${ }^{4}$ In addition, Katherine Phelps has drawn our attention to the astonishing lack of reference to practical midwifery. The author claimed to pursue a necessary balance between speculative and practical knowledge, but the focus of the treatise is heavily weighted in favour of theoretical learning and subjects of debate, including a lengthy opening book devoted to a survey of both male and female reproductive organs. In contrast, there is a striking absence of case histories or specific personal experience to

\footnotetext{
${ }^{1}$ While supporting the contemporary preference for the term "involuntary childlessness", which focuses our attention on the social and psychological consequences of an individual's or couple's experience of biological infertility, in this article I use the term "infertility" in order to explore the early modern medical conception of this state. I use "infertility" throughout this article as the standard translation of the noun "stérilité", which regularly occurs in the sixteenth- and seventeenth-century French medical texts I shall cite.

2 Recent critics, with the exception of Evenden (8-11,) generally assume the authors of an earlier compendium in English, The Complete Midwifes Practice (1656), to be male. (See O'Hara's judicious summary of the case in Louise Bourgeois 74, n. 25). This compendium was largely derived, without acknowledgement, from continental male authors and from Louise Bourgeois; four sets of initials are the only indication of its authors' possible identity.

${ }^{3}$ In her excellent edition of Sharp's text, Elaine Hobby, although assuming the author to be a female midwife called Jane Sharp, acknowledges at the outset that 'We do not know who Jane Sharp was' (xi).

${ }^{4}$ For example Morphis has argued that even if the biographical identity and gender of the author cannot be determined, this does not prevent us from recognising the author's construction of a female voice (e.g. Morphis 167, 191 n.6).
} 
authenticate the author's claims to be a midwife. This leads Phelps to conclude that "it seems very likely that 'Sharp' was in fact a man writing in 'drag"' (Phelps 237). So we have the conundrum of a successful book purporting to be by a midwife but probably male-authored, laden with theory yet very light on practice, and which foregrounds the biology of reproduction. This captures the paradoxes surrounding the female reproductive body: it belonged within the theoretical remit of physicians, yet only midwives saw and touched the pudenda. Hence, to claim the authorship of a midwife suggested an imprimatur of privileged professional experience.

Sarah Stone's refusal to engage in any discussion of female infertility on the other hand, shows a practising midwife distancing herself from theoretical pronouncements. She rested her case for publishing her work on her extensive skills as an expert in difficult deliveries, the core activity - in her view,- of a good midwife. In this, she resembles, on one level, her German predecessor, the midwife Justine Siegemund. ${ }^{5}$ Siegemund's work, The Court Midwife, published in 1690, concentrates entirely on the process of birth, and pays particular attention to how the midwife should conduct difficult deliveries. Siegemund does not eschew all theory in her treatise; indeed, she starts her work with a full account of the physiology of a normal birth. However, like Stone, she does not include any discussion of conception or of obstacles to fertility. For her, this was not part of midwifery practice.

Both Stone and Siegemund stand in contrast to the French midwife Louise Bourgeois, who was the first early modern midwife to publish her professional observations, her three volumes, appearing in 1609, 1617 and 1626. Thanks to the fine recent translation by Stephanie O 'Hara, expertly introduced and annotated by Alison Klairmont Lingo, anglophone historians of childbirth and of women's history are now able to compare Bourgeois's writings with those of her English and continental counterparts. In this article, I shall explore how and why, unlike these later midwives, Bourgeois explicitly includes advice on conception and female infertility among a midwife 's duties, and what this indicates about her perception of the authority of a midwife.

\section{Situating discussions of infertility within an early modern midwife`s work}

Bourgeois`s position might initially seem unremarkable, since in earlier centuries a midwife`s role had encompassed care during pregnancy, and possibly advice on conception. However, infertility was an area, as Monica Green has shown, which throughout Europe was increasingly colonised by male physicians, from the fifteenth century onward. Likewise, Katherine Park has used evidence from the thirteenth to the fifteenth centuries to demonstrate how Italian women were already turning to physicians for advice on how to conceive. ${ }^{6}$ At first sight, it is, therefore, tempting to see Bourgeois's inclusion of these topics as reclaiming an area of expertise which previously midwives had ceded too easily to physicians. Yet Samuel Thomas has rightly cautioned historians against assuming all early modern midwives can be grouped together purely by virtue of their profession, without due regard for factors such as their social status and context (Thomas 118). It is important, in this respect, to bear in mind that Bourgeois was married to a respected surgeon, and moved in the circle of elite physicians and surgeons in Paris and the court. She writes with a confidence born of her own experience but also of her first-hand knowledge of the professional competences (and limitations) of other medical practitioners. She is, for example, voluble in her denunciation of the growing fashion for male midwives to conduct deliveries among elite Parisian women (Bourgeois 272). However, as we shall see, her discussion on infertility is not framed as an

\footnotetext{
${ }^{5}$ See the translation and critical edition by Tatlock.

${ }^{6}$ See the discussion of this evidence by Lingo (Louise Bourgeois 36, n. 75).
} 
attack on physicians, nor is it defensive in tone. Instead, she offers a confident exposition, ostensibly for a lay readership, but which also clearly demonstrates her professional insights.

It is important, from another perspective, to test Bourgeois's position against the light which both Mary Fissell and Lisa Cody have shed on the relationship between the rise of male midwifery and the increasing masculinisation of science, especially of gynaecological and obstetric knowledge, in seventeenth and eighteenth century England. Given Bourgeois`s work appeared on the cusp of a series of western European epistemological shifts, we need to ask whether her writings on infertility seek to articulate a new scientific understanding? Or, rather, are included in her first volume as part of the practical insights of an expert and highly reflective midwife? ${ }^{7}$

Finally, an analysis of Bourgeois's accounts of female infertility is the more timely in that, despite the extensive interest over the last thirty years in women's reproductive health and in their experiences of pregnancy and birth in early modern Europe, there has been relatively little scholarship on the subject of infertility. As recently as 2016, Daphna Oren-Magidor and Catherine Rider argued in their introduction to The Social History of Medicine's special issue on this theme, "The history of infertility in general, and in pre-modern periods in particular, is still in its infancy." (Oren-Magidor and Rider 222). The Palgrave Handbook of Infertility in History, which appeared in 2017 (edited by Gayle Davis and Tracey Loughran), is a welcome advance, but only two of some thirty contributions concern the early modern period, and Bourgeois is cited only once (Roberts 158). I propose to demonstrate here that her writings on infertility are precious for historians of medicine, as well as for women's history and social history because they offer a rare example of how an experienced female practitioner advised her clients. ${ }^{8}$

The title of the first volume of Bourgeois's published work makes it the more surprising that her treatment of infertility has been overlooked, since it begins with precisely this theme: Diverse Observations on Sterility, Miscarriage, Fertility, Childbirth, and the Diseases of Women and Newborn Children [Observations diverses sur la sterilité, perte de fruict, fœecondité, accouchements et maladies des femmes et enfants nouveaux naiz]. However, this apparent prioritisation of infertility and fertility occurs only because the title of the volume functions as a summary of the contents of the first volume, in which Bourgeois follows the conventional organisation of textbooks on pregnancy and birth by medical men. The first thirty-five of her fifty chapters move chronologically from conception and pregnancy to birth and the postpartum period. Chapter 36 , in contrast, provides an innovative transition, making the argument that midwives should study the anatomy of the womb (through attending dissections); in this respect, Bourgeois places the training of female practitioners alongside that of surgeons and physicians. Finally, the last thirteen chapters constitute the "diverse observations", or case histories, drawn from Bourgeois's own practice, with the very last chapter addressing a range of general questions on premature births, milk supply, and so forth. The focus on personal case histories is likewise foregrounded in the first twenty-three chapters of Book II (published in 1617). Bourgeois seems unconcerned to order these to form a coherent overview, certainly not one that mirrors the stages of conception and labour. A very long twenty-fourth chapter is devoted to 'Illnesses of the Womb' (a standard subject of medical textbooks for physicians), before the reader reaches the more innovative, autobiographical sections. These

\footnotetext{
7 See the discussion by Rouget in his article on Bourgeois`s powers of reflection.

${ }^{8}$ In her discussion of what can be discovered about aphrodisiacs to stimulate fertility or cure infertility in early modern England, Jennifer Evans teases out the difficulty of distinguishing between lay people's use of information circulating in printed works as opposed to their recourse to unwritten, popular sources (Evans 3334. 38-39). In this respect, Bourgeois's comments allow us to identify what information the midwife believed she conveyed to her clients.
} 
comprise her report of viewing the `stone [petrified] foetus` of Sens; her account, for her daughter of 'How I learned the Art of Midwifery', and finally her 'True Account of the Births of My Lords and Ladies the Children of France'. Book III (published in 1626) is far shorter than the previous two volumes. It contains further case histories (with reflections) and some recipes or remedies, again without any apparent overarching order to the chapters. In short, the theme of infertility is present as the traditional entry point into the subject matter of pregnancy and childbirth, at the start of volume I; thereafter it is touched on only through occasional, passing remarks within several of the case histories.

\section{How surgeons and physicians discussed infertility in later sixteenth-century French medical texts}

Given that Bourgeois treats the subjects of infertility and repeated miscarriage (viewed by early modern medicine as a form of infertility) in a context inherited from male authors, we need to establish how surgeons and physicians discussed these topics in Renaissance French medical texts. It is significant that the first book in the vernacular devoted entirely to difficulties in conception appeared while Bourgeois was still professionally active, namely Louis de Serres's treatise of nearly 500 pages, Discours de la nature, causes, signes, et curation des empeschemens de la conception, et de la sterilité des femmes, published in Lyons in 1625. Juxtaposing literary, historical and medical texts with material culture, Holly Tucker has explored the almost obsessive interest in fertility in early seventeenth-century France, linking it to the kingdom's wait for the birth of an heir to Anne of Austria. De Serres, whose concluding remarks specifically mention the queen (de Serres 485-486), ${ }^{9}$ is a prime example of this concern. Bourgeois had similarly captured the expectations of a nation waiting for an heir after three successive sixteenth-century French kings had died without a son to succeed them (Roberts 151-169). Her full and vivid account of the birth of the dauphin - the future Louis XIII - to Marie de Medici in 1601 celebrates the end of the nation's earlier wait (Bourgeois 250257).

Even before fertility and infertility took centre stage in their own right, however, medical textbooks in French treated the topic within broader discussions of reproductive health (WorthStylianou, Les Traités d'obstétrique 21-54). While these works in the vernacular drew extensively on the writings of their classical and medieval predecessors, ${ }^{10}$ and sometimes also on the volumes many learned physicians continued to produce in Latin, it is helpful here to focus on works in French which Bourgeois herself, as well as surgeons and other literate midwives, could have read. ${ }^{11}$ I propose to consider three volumes published in the later sixteenth century which specifically treat female infertility:

- Ambroise Parés De la generation de l'homme (1573). The king`s surgeon explained the anatomy and processes of conception, pregnancy and birth. ${ }^{12}$

- Laurent Joubert's Erreurs populaires (1578). Authored by the Chancellor of the Faculty of Medicine at Montpellier, the best-selling work corrected popular myths about conception,

\footnotetext{
${ }^{9}$ See annotated English translation in Worth-Stylianou, Pregnancy and Birth 347-348.

${ }^{10}$ For an excellent overview of classical Greek writings on infertility, see Flemming 565-590.

${ }^{11}$ She refers in passing to Galen and Hippocrates (e.g. Bourgeois 204, 303), but although many of her practices engage with ancient theories - whether to uphold or contest them-, as Klairmont Lingo's footnotes show, there is no other evidence that Bourgeois had read these authors or was deliberately drawing on their writings.

${ }^{12}$ See Worth-Stylianou, Les Traités d’obstétrique 119-122, 135-140.
} 
sexuality, pregnancy, birth, and the puerperium, while adding surprising and sometimes amusing medical anecdotes. ${ }^{13}$

- Jean Liébault's Trois Livres (1582). This well-known Parisian physician and medical author adapted and extended (without acknowledgement) a work on female reproductive health, which had been written several decades earlier by the Italian physician Marinelli. ${ }^{14}$

We know from Bourgeois's own account of how she became a midwife that she chose to study the writings of Ambroise Paré. A local midwife, eager to persuade Bourgeois to join this profession, suggested that Martin Boursier's position as a surgeon who had formerly studied and worked with Paré was a distinct advantage (Bourgeois 234). ${ }^{15}$ Furthermore, when Bourgeois - with at least a show of reluctance- accepted her calling, she records that she "began to study Paré's work" before undertaking her first delivery (Bourgeois 234), and claims it was her memory of what she had read which prompted her to act in a way that saved the new mother's life:

I had read and remembered that you should not let a woman who has just given birth go to sleep, lest weakness due to the delivery carry her off. (Bourgeois 234)

In this depiction of herself as a well-read midwife, ${ }^{16}$ Paré provides an authoritative reference. Although he died in 1590, some years before Bourgeois took up midwifery, the inclusion of his name also reminds the reader of her family's connections with elite surgeons and physicians. ${ }^{17}$ In addition, it echoes her mention in the first volume of the Observations, in 1609, of Paré's De la generation, in order to support her observation that anger can cause miscarriage. ${ }^{18}$ This reference is the more significant given Bourgeois`s general disinclination to attribute her knowledge to a specific source. ${ }^{19}$

In the cases of Joubert and Liébault, we cannot determine whether Bourgeois read either herself, since their names are not cited. However, so few written sources are specified in the Diverse Observations that the absence of direct reference is not in itself conclusive. ${ }^{20}$ It is nonetheless important to consider both here for two reasons. First, these works circulated particularly widely in the thirty years preceding the publication of Bourgeois`s first volume making it possible that she, or her husband, or the medical circles in which she moved, knew them. Their ideas may thus have percolated into the Diverse Observations at least indirectly. Secondly, these works, like Parés, are

\footnotetext{
${ }^{13}$ I shall cite Joubert in the annotated modern English translation by de Rocher; see also WorthStylianou, Les Traités d'obstétrique 187-226.

${ }^{14}$ See Worth-Stylianou, Les Traités d'obstétrique 257-268 ; Worth-Stylianou, Pregnancy and Birth 63-137.

${ }^{15}$ However, Madame Dupuis, one of the sworn senior midwives who examined Bourgeois, apparently distrusted her for precisely the same reason, expecting that she would be in league with physicians and surgeons to the disservice of midwives (Bourgeois 235).

${ }^{16}$ Klairmont Lingo's account of the training and education of midwives sets the wider professional context (Bourgeois 27-30).

${ }^{17}$ She records being present at his deathbed (Bourgeois 303-304).

18 " [...] which made me think that her anger had something to do with it, according to what Paré says in his book entitled Of the Generation of Man [...]". (Paré 114).

${ }_{19}$ Nonetheless, Klairmont Lingo's footnotes on Bourgeois`s Diverse Observations are replete with references to Paré's De la generation, as a proxy for late Renaissance medical teachings on pregnancy and childbirth, indicating Bourgeois may have known them very well.

${ }^{20}$ One notable exception to her disinclination to cite specific classical authors occurs when she refers, in close succession (Bourgeois 204) to Hippocrates on children born at seven months, and to Hippocrates and Galen on the signs of a stillborn child.
} 
directly relevant for our discussion of how infertility was understood and presented in France in this period. In contrast, the topic is omitted in various other well-known works on women's reproductive health either written in French or translated into French- from the French translation of Rösslin's Birth of Mankind to A Happy Delivery by the Paris surgeon Jacques Guillemeau (the latter appearing in 1609 , the same year as Bourgeois`s first volume). ${ }^{21}$

In order to establish what is specific to Bourgeois's treatment of infertility and early miscarriage, I shall outline the organisation and indicate the extent of the discussion of these themes in each of the male authors. ${ }^{22}$

\begin{tabular}{|c|c|c|}
\hline $\begin{array}{l}\text { Ambroise Paré, De la } \\
\text { generation de I'homme } \\
\text { (1575) }\end{array}$ & $\begin{array}{l}\text { Laurent Joubert, Erreurs } \\
\text { populaires (1578) }\end{array}$ & $\begin{array}{l}\text { Jean Liébault, Trois Livres } \\
\text { (1582) }\end{array}$ \\
\hline $\begin{array}{l}\text { Ch } 37 \text { : miscarriages } \\
\text { Ch } 43 \text { : male infertility } \\
\text { Ch } 44 \text { : female infertility } \\
\text { [Chs } 45-72 \text { general } \\
\text { discussions of diseases of } \\
\text { the womb, menses and } \\
\text { female discharges] }\end{array}$ & $\begin{array}{l}\text { Bk II: Conception } \\
\text { Ch 1-3, 10-11 aspects of female } \\
\text { fertility and infertility } \\
\text { Ch 6-7, 9-10 aspects of male } \\
\text { fertility and infertility } \\
\text { Bk III: Pregnancy } \\
\text { Ch 5-6: some causes of } \\
\text { miscarriage }\end{array}$ & $\begin{array}{l}\text { Bk II: Infertility } \\
\text { Ch 1-11: nature, symptoms, } \\
\text { causes of male and female } \\
\text { infertility } \\
\text { [Ch } 12-27 \text { further discussion of } \\
\text { diseases of the womb, menses } \\
\text { and female discharges] }\end{array}$ \\
\hline
\end{tabular}

We can see that in Joubert, the themes are treated in a limited number of chapters, and he makes no claims of comprehensive coverage. In contrast, Paré and Liébault both provide a complete compendium on reproduction and issues around fertility, whether primarily from the perspective of the surgeon (Paré) or the physician (Liébault). Liébault's treatment of the subject of infertility is notably longer, and his discussion of afflictions of the womb and menstrual cycle is particularly detailed, as befits a physician's approach. ${ }^{23} \mathrm{He}$ also pays particular attention to unbalanced male and female humours resulting in the infertility of a couple; this underlies his choice to treat male and female sterility together rather than (as Paré does) in separate chapters. Nonetheless, these differences between how the treatment of infertility is organised in Paré and Liébault are less significant than the contrast between the extended coverage they both offer in contrast with just two chapters accorded to the theme in Bourgeois. Infertility may be the first theme mentioned in her title, but, as a practising midwife, pregnancy and birth constitute the main focus of her volume.

${ }^{21}$ See Worth-Stylianou Les Traités d'obstétrique 89-117 (Rösslin) and 361-373 (Guillemeau) ; and Worth-Stylianou, Pregnancy and Birth 139-219 (Guillemeau).

${ }^{22}$ The chapters indicated in square brackets bear on infertility, but this is not the primary focus.

${ }^{23}$ Translating from Marinelli's Italian work, but supplementing it liberally with his own material, he draws extensively, with precise references, on a wide range of classical sources, notably Hippocrates, Galen and Aristotle. However, he offers corrective readings of classical authorities where he believes that Renaissance anatomists and physicians (Fernel, Faloppius, etc) have discovered new truths. 
What of the substance of the three male authors accounts of female sterility? ${ }^{24}$ While each writer's emphasis is different according to their professional and individual perspective, ${ }^{25}$ there is no disagreement on the principal causes and main remedies. Physiologically, as would be expected in the early modern era, they all rely on humoral medicine, in other words promoting the ideal of the balanced temperament of the woman, and looking to adjust any imbalance caused by internal or external factors. Their understanding of the anatomy of the female reproductive body is central, since any malformation of the womb or genitalia is identified as another common cause of infertility. Again unsurprisingly, in their lengthier expositions, both Paré and Liébault concentrate particularly on the womb and the menses as key to the problem. All three authors indicate a wide range of tests (many dating back to classical authors e.g. Liébault 186-188) in order to establish whether a woman or a couple are fertile, and to identify the precise causes of infertility. This empirical evidence must be accompanied by rational deduction, above all - in the eyes of Liébault and Joubert - the province of the physician. ${ }^{26}$

However, in his comprehensive survey, Liébault also accords specific roles to the surgeon and to the midwife, whose significance is thereby implicitly recognised for both the diagnosis and cure of infertility. When he discusses possible malformations of the woman's reproductive organs, he recommends that external abnormalities (including of the flow or nature of the menses) "must be noted with great judgement and discernment" [se doivent remarquer avec grand jugement et discretion" (Liébault 194)]. In contrast, for potential abnormalities of the cervix, the physician must rely on the report of either the husband, or the midwife who may examine these internal parts. ${ }^{27}$ Similarly, it is the midwife's finger which should check if the womb is misaligned (Liébault 442), sits too low or has prolapsed (Liébault 444, 450), or if the cervix is too open (Liébault 474). Where an anatomical abnormality may require surgical correction, on the other hand, such as in the case of an obstruction at the entrance to the vagina, he expects the surgeon to conduct the internal examination, using a speculum, and to undertake the treatment (Liébault 500).

In short, the evidence of the three male authors suggests that there is a broad consensus on the nature, signs, causes and range of treatments for female infertility, and there is no obvious disagreement about which practitioner - in the multi-practitioner setting of larger towns, at least should undertake a given part of the treatment. While each of Paré, Joubert and Liébault can, on occasion, be very critical, even scathing, with regard to those incompetent midwives who inflict

\footnotetext{
${ }^{24}$ Since Bourgeois discusses only female sterility within the province of the midwife's expertise, I shall leave aside here the discussion of male infertility by Paré, Joubert and Liébault.

${ }^{25}$ For example, in terms of humoral imbalance Joubert argues that in most cases the woman's womb is too hot and dry, rather than, as is commonly believed, too cold and damp (Popular Errors 121-122). Liébault is distinctive in his emphasis on the importance of a positive sexual relationship for conception; for example, in II.2 he argues that if a man ejaculates too soon before a woman has experienced pleasure, this may impede conception.

${ }^{26}$ Paré is unusual among surgeons, in part because of his privileged role as royal surgeon, for the confidence with which he explains physiology as well as anatomy, and assumes he has the competence to treat some female reproductive problems independently. It should nonetheless be remembered that in $\mathbf{1 5 7 5}$ he aroused the wrath of the College of Physicians in this respect (WorthStylianou "The definition" 150-153).

27 "le mary seul en doit ester le juge: ou pour luy la sage femme qui maniera et tentera les lieux" (Liébault 194).
} 
injuries on their patients ${ }^{28}$ - as indeed is Bourgeois herself (Bourgeois 122) -, they accept that midwives will play a role in the treatment of female infertility.

\section{What is distinctive about Bourgeois`s discussion of the theme?}

When we turn to Bourgeois`s two chapters on women unable to conceive or to prone to early miscarriage, we find a similar recognition, of the benefit of good collaboration between midwife and male practitioners. Except when male surgeons are threatening to supplant the female midwife at a birth (Bourgeois 278), or when she judges an individual physician or surgeon has been incompetent, Bourgeois generally promotes a vision of professional cooperation between herself and her male colleagues ${ }^{29}$ This strategy casts her in a strong light, since she regularly depicts male practitioners seeking her advice and implicitly affirming her expertise (e.g. Bourgeois 128, 169, 174, $198,200,215,293)$.

While Bourgeois's discussion on infertility is not notable for its length or comprehensiveness, in what ways are the substance or the style of her approach nonetheless distinctive in comparison with her male counterparts? Unlike them, she does not venture to discuss male infertility, asserting in her opening paragraph:

Insofar as men are concerned, I will leave it to those of their sex, knowing that they can openly discuss it together. (Bourgeois 104)

As far as the possible causes of both female infertility and early miscarriage are concerned, those that she names are all found in her male counterparts. I list order in which she introduces them:

\begin{tabular}{|c|c|}
\hline Causes of female infertility (Book I ch. 1) & Causes of early miscarriage (Book II, ch. 2) \\
\hline $\begin{array}{l}\text { Two main causes: } \\
\text { 1. woman's over- choleric blood } \\
\text { 2. womb too moist and cold (midwife } \\
\text { recognises this; physician can treat with } \\
\text { medicines to promote dry humours) } \\
\text { The following detailed causes are then } \\
\text { identified: } \\
\text { - disease of womb - the whites (should } \\
\text { - be treated internally) } \\
\text { cold humours causing the womb to lie } \\
\text { - owkwardly or a hardened cervix } \\
\text { over-narrow vagina preventing full } \\
\text { - over-heated blood, caused by poor } \\
\text { diet, strong wine, strong food } \\
\text { - green sickness (i.e. melancholic } \\
\text { humour) }\end{array}$ & $\begin{array}{l}\text { 1. anger (disturbing the blood), the most } \\
\text { common cause } \\
\text { 2. accidental loss through inadvertent injury } \\
\text { 3.(avoidable) loss - over-tight corsets, harmful } \\
\text { foods, dancing, immoderate use of carriages, } \\
\text { horse-riding } \\
\text { 4. being purged or bled without advice from } \\
\text { physician } \\
\text { 5. woman seeking early internal examination to } \\
\text { confirm pregnancy from (an over-intrusive) } \\
\text { midwife } \\
\text { 6. thin or insufficient blood } \\
\text { 7. falls caused by lack of stability in pregnancy } \\
\text { 8. raising hands above the head (dangerous in } \\
\text { some but not all women) } \\
\text { 9.any extreme loss of blood }\end{array}$ \\
\hline
\end{tabular}

${ }^{28}$ E.g. mistaking the uterus for the placenta, and pulling on it to extract the afterbirth, thereby causing a prolapse (Liébault 445 ).

${ }^{29}$ For a fuller analysis of the shifts and complexities within Bourgeois's relations with male medical professionals, see the article by Perkins. 
However, within this conventional conceptual framework, her own voice is clearly heard. From the very first paragraph, her remarks are based upon her observations during her practice of midwifery:

In the course of my practical experience in these matters, I have taken note of all that I possibly could about the reasons behind [impediments to pregnancy]. (Bourgeois 104)

Thus, she assigns the priorities these observations have taught her to recognise:

The cause of the first and most frequent impediment to pregnancy is that the female sex is extremely moist and nevertheless choleric. (Bourgeois 104)

or,

The most common occurrence that causes women to give birth before the time is anger.

(Bourgeois 114)

Nor is she hesitant in giving advice not only on physical matters but also on what she believes to be the association between a woman`s moral conduct and her fertility:

I will say that on rarer occasions, there are women who heat up their blood so much that it is quite burned and excessively choleric. This occurs due to a poor diet, with a bad habit of drinking too much strong wine [...]. (Bourgeois 108)

Even more striking is her vicious harangue of women who, she believes, contribute wilfully to their early miscarriages by reckless behaviour ("dancing, travelling in carriages, riding horseback on a difficult horse", Bourgeois 116). The reason for Bourgeois's outrage - as she invokes divine wrath on these women to punish them even in the afterlife ${ }^{30}$ - lies in her strong Catholic belief in a mother's duty to do all in her power, assisted by her midwife, to bear a child who will live long enough to receive the sacrament of baptism. ${ }^{31}$ It is true that male medical writers may adopt a similar line of argument, but in Bourgeois's case we see that, at the conclusion of chapter 2, she is particularly concerned to distinguish the midwife who fulfils her duty under the professional oath she has sworn from those midwives who act as secret but willing accomplices of prostitutes. Although she refrains from naming it thus ("This deserves another name than that of midwife", Bourgeois 123), she is all too aware that, in her own society, midwifery could be tainted by association with procuresses and abortionists. For a midwife to discuss miscarriage in print, she must prove the moral high ground she occupies to be above suspicion.

Bourgeois offers the reader clear guidance on the role of the various medical practitioners in treating infertility, and for the most part this does not conflict with the positions adopted by Paré, Joubert and Liébault. She is almost certainly influenced not only by her professional experiences but also by her connections both at court and among the Parisian elite, and by her family insights as the wife of a surgeon (and, by 1617, mother-in-law of a physician, and mother of an apothecary). ${ }^{32}$ The

\footnotetext{
30 "if a poor miserable woman forgets herself so much as to rid herself of a child, she is justly condemned to die as an example. Do those women who are not punished in this world think they can escape God's justice? No, no they are wrong; He is just and rigorous. Would to God that the punishment of such women could be increased [...]." (Bourgeois 115).

${ }^{31}$ On Bourgeois`s religious position, see Klairmont Lingo's analysis (Bourgeois 34-35).

32 In her advice to her daughter who wishes to become a midwife, she says: "For you are the child of a family in which your sister's husband is a physician, your husband is studying to become one, one
} 
physician in particular is credited with the role of diagnosis. For example, she believes that whereas a midwife diagnoses diseases through internal examination or "touch", it requires a good physician to recognise when a woman suffers from choleric blood, since this is an internal malady resulting from a humoral excess:

These women show no outwards signs of infertility that can be discerned by touch. The problem is entirely an internal one; a learned physician who recognises this can easily heal it. (Bourgeois 105)

In contrast, it is the skilled midwife's examination which allows her to attribute female infertility to an over-narrow cervix obstructing the passage of the menses.

If a midwife who knows her art were to touch such women, she would judge that the neck of the womb, being long and hard, was not capable of receiving a child. This is because the obstacle in the womb is simply the retention of this thick menstrual blood. (Bourgeois 107)

We should note this statement also implies that the midwife is not merely a practitioner, relying on a manual examination; she must also judge what she finds, and it is assumed she will understand the underlying physiology, both skills usually associated with physicians' theoretical knowledge.

However, in her advice on infertility, Bourgeois is careful to refer her patient back to the physician for decision about treatment. Indeed, in discussing how women should avoid the risk of early miscarriage, she recommends a relationship of total trust between female patient and physician, comparable to that between a woman and her confessor:

If they feel themselves subject to some fluxions, illnesses, or severe blood loss, they are required to send for learned physicians at once and explain their difficulties to them in order to prevent future illness, confiding everything to the physicians as if they were declaring their sins to their confessor. (Bourgeois 116)

Bourgeois is envisaging the ideal "learned physicians", but it is nonetheless clear that she accepts the status quo whereby a physician takes responsibility for the patient's general health. ${ }^{33}$ Furthermore, in the same chapter, she is critical of less skilful midwives who, by their collusion with imprudent women, risk causing them to suffer an early miscarriage through premature vaginal examinations:

Women can have themselves examined without harm resulting from it, but they must be well assured of the discretion and experience of the woman who examines them. (Bourgeois 116)

It would seem, therefore, that Bourgeois's respect for the physician's traditional role leaves the midwife with a valuable but circumscribed role in respect to female infertility: the midwife must conduct internal examinations, but the physician will be called upon to prescribe treatment. In addition, she concludes her chapter on early miscarriages with a strong defence of calling in a surgeon if a woman in later pregnancy is haemorrhaging severely, or indeed in a situation where a surgeon can save the woman's life. In 1609, her position is unequivocal, and conforms closely to the

of your brothers is an apothecary, your father is a surgeon, and I am a midwife. The entire body of the medical profession is represented in our household." (Bourgeois 267).

${ }^{33}$ C.f. her conclusion, later in this chapter, to a case history: "This is why it is very important for a woman to call the physician in order to have him understand what her constitution is, so that by his prudence he can act as he judges best." (Bourgeois 121). 
1560 statues and regulations of midwifery in Paris, which stipulated that a surgeon should be called into difficult labours:

Some will be astonished by my saying that if a midwife cannot do this, she should have a good surgeon sent for: extreme situations call for extreme remedies, especially since midwives may only see things go badly one time out of a hundred and so are likely to be perplexed when they do go badly. (Bourgeois 122)

Can this be the same Bourgeois who, in 1617, denounces male-surgeons taking over deliveries? I would suggest the answer lies in two factors. First, her defence of calling in a surgeon concerns only abnormal or dangerous labours. Secondly, by 1617 she articulates a growing awareness of the increasing professional threat to midwives of surgeons specialised in deliveries in Paris. However, even in 1609, her position is not without nuance. The surgeon sent for must be "good"; and the midwife will call him when (and only when) she recognises that the situation is beyond her competence.

This last distinction brings us also to the dichotomy the reader may sense between Bourgeois`s apparent deference, in the two chapters on female infertility, to physicians and even surgeons, and yet the confidence with which she recounts her own medical experiences. Precisely because she is an exceptionally observant and reflective midwife, her written observations oscillate between detailing the standard role a midwife will perform, and yet also proffering far more general reflections on female health. It is notable, for example, that she regularly uses phrases of the kind "I have seen such women treated with..."; 34 "I will say that on rarer occasions there are women who ..."; ${ }^{35}$ and "I will say that in most women, pregnancy does not...". ${ }^{36}$ Although she is not formally claiming an extended remit, her case histories and her reflections upon them make the reader consider her as a voice of authority. In addition, she brings her subject matter within the reader's grasp by using plain language and vivid, everyday images which are easily understood and memorable. For example, she says of an over-narrow cervix:

instead of resembling the closed opening of a money-bag, it rather resembles a small flute, not at all in length, but in narrowness, such that the menstrual blood can hardly pass through. (Bourgeois 107)

Or the product of an early miscarriage is described as:

a large membrane, thicker on one end than the other, like a duck's egg, in which there was red water and many white filaments, with three glands like little grains of crystal. (Bourgeois 114)

Bourgeois's achievement is to speak directly to her reader in a voice which has the authority of experience, in a language which is easily comprehensible yet never trivialising, and with the immeasurable appeal of speaking of women's secrets from her own observations. Her treatment of female infertility may constitute only a small part of her total work, but in commencing in traditional fashion with this subject, she convincingly sets the tone for the reader's journey through the rest of

\footnotetext{
34 A reference to physicians successfully employing "desiccating substances" to treat infertile women who suffer from "a great deal of moisture in the womb" (Bourgeois 105).

${ }^{35}$ A reference to women who suffer from too much heat rather than too much moisture, so that their blood is "quite burned and excessively choleric", a condition which she ascribes to their consuming strong foods and too much strong wine (Bourgeois 109).

${ }^{36}$ A reference to many pregnant women experiencing some "form of illness-, such as nausea, "weakness" (i.e. a predisposition to faintness) and pica (Bourgeois 116).
} 
her writings. She would not have disagreed with one part of Sarah Stone's assessment somewhat over a century later, in England, namely that "Teeming Women ought to commit themselves to the Care of a Physician" for some of their "Disorders", but she would surely have repudiated Stone's absolute statement that "all the Disorders of Teeming Women do not belong to Midwives". For Bourgeois, the care of women's fertility and infertility depends on a mutually respectful collaboration between the female midwife and the male physician.

\section{Valerie Worth-Stylianou}

University of Oxford

\section{Works Cited:}

Anon. The Compleat Midwifes Practice. London, 1656.

Bourgeois, Louise. Midwife to the Queen of France: Diverse Observations. Translated by Stephanie O`Hara, edited by Alison Klairmont Lingo, Iter Press, 2017. The Other Voice in Early Modern Europe.

Cody, Lisa Forman. Birthing the Nation: Sex, science, and the conception of eighteenth-century Britons, Oxford University Press, 2005.

Davis, Gayle and Tracey Loughran (ed.). The Palgrave Handbook of Infertility in History. Palgrave Macmillan, 2017.

Evans, Jennifer. Aphrodisiacs, Fertility and Medicine in Early Modern England. The Boydell Press, 2014.

Evenden, Doreen. The Midwives of Seventeenth-Century London. Cambridge University Press, 2000. Cambridge Studies in the History of Medicine.

Fissell, Mary. Vernacular Bodies. The politics of reproduction in early modern England. Oxford University Press, 2004.

Flemming, Rebecca. "The Invention of Infertility in the Classical Greek World: Medicine, Divinity, and Gender." Bulletin of the History of Medicine, vol. 87, Winter 2013, pp. 565-590.

Green, Monica. Making Women's Medicine Masculine: the rise of male authority in pre-modern gynaecology. Oxford University Press, 2008.

Joubert, Laurent. Erreurs populaires. Bordeaux, 1578.

------, Popular Errors. Translated by G. de Rocher, University of Alabama Press, 1989.

Liébault, Jean. Trois Livres appartenant aux infirmités et maladies des femmes. Paris, 1582.

Oren-Magidor, Daphna and Catherine Rider. "Introduction: Infertility in medieval and early modern medicine', Social History of Medicine, vol. 29, no. 2, 2016, pp. 211-223.

Morphis, Catherine, "Swaddling England: How Jane Sharp's Midwives Book shaped the body of early modern reproductive tradition." Early Modern Studies Journal vol. 6, 2014, pp. 166-194.

Paré, Amboise. Deux Livres de chirurgie. 1. De la generation de l'homme [...]. Paris, 1573. 
Park, Katherine. Secrets of Women: gender, generation, and the origins of human dissection. Zone Books, 2006.

Perkins, Wendy. "Midwives versus Doctors: The case of Louise Bourgeois." The Seventeenth Century, vol. 3, 1988, pp. 135-157.

Phelps Walsh, Katharine. "Marketing Midwives in Seventeenth-Century London: A Re-examination of Jane Sharp's The Midwives Book." Gender \& History vol. 26, no. 2, 2-14, pp. 223-241.

Roberts, Penny. "Sterility and Sovereignty: The succession crisis of the late Valois monarchy." The Palgrave Handbook of Infertility in History, edited by Gayle Davis and Tracey Loughran, Palgrave Macmillan, 2017, pp. 151-169.

Rouget, François. "De la sage-femme à la femme sage : réflexion et réflexivité dans les Observations de Louise Bourgeois." Papers on French Seventeenth-Century Literature, vol. 48, no. 9, 1998, pp. 483496.

Serres, Louis de. Discours de la nature, causes, signes, et curation des empeschemens de la conception, et de la sterilité des femmes. Lyons, 1625.

Sharp, Jane. The Midwives book or the Whole Art of Midwifry, 1671. Edited by Elaine Hobby, Oxford University Press, 1999. Women Writers in English 1350-1850.

Siegemund, Justine. The Court Midwife. Edited and translated by Lynne Tatlock, University of Chicago Press, 2005. The Other Voice in early Modern Europe.

Stone, Sarah. A Complete Practice of Midwifery. Consisting of upwards of forty cases or observations in that valuable art. London, 1737.

Thomas, Samuel S. "Early modern midwifery: splitting the profession, connecting the history." Journal of Social History, vol. 43, no. 1, Fall 2009, pp. 115-138.

Tucker, Holly. Fictions: Childbirth and the Fairy Tale in Early-modern France. Wayne State University Press, 2003.

Wilson, Adrian. The Making of Man-Midwifery, Childbirth in England 1660-1770. Harvard University Press, 1995.

Worth-Stylianou, Valerie. Les Traités d’obstétrique en langue française au seuil de la modernité. Geneva, 2007. Travaux d’Humanisme et Renaissance.

-----, "The definition of obscene material 1570-1615: three medical treatises held to account." Early Modern France, vol. 14, 2010, pp. 148-167.

------, Pregnancy and Birth in Early Modern France: treatises by caring physicians and surgeons (15811625). Edited and translated by Valerie Worth-Stylianou. Iter Press, 2013. The Other Voice in Early Modern Europe. 